\title{
PENGARUH KEMAMPUAN BERBAHASA INGGRIS TERHADAP HASIL BELAJAR PEMROGRAMAN BERORIENTASI OBJEK PADA IMPLEMENTASI KURIKULUM ORACLE ACADEMY
}

\author{
Luh Joni Erawati Dewi'), A.A. Gede Yudhi Paramartha'), I Ketut Purnamawan ${ }^{3)}$ \\ 1,2,3 Fakultas Teknik dan Kejuruan, Universitas Pendidikan Ganesha \\ Email: ${ }^{1 j o n i . e r a w a t i @ u n d i k s h a . a c . i d ~}$
}

\begin{abstract}
ABSTRAK
Oracle Academy merupakan inisiatif dari Oracle untuk mendukung pendidikan ilmu komputer di dunia. Oracle Academy menyediakan beberapa kurikulum yang siap pakai oleh berbagai instansi pendidikan di dunia. Jurusan Teknik Informatika, Fakultas Teknik dan Kejuruan, Universitas Pendidikan Ganesha juga telah menerapkan salah satu kurikulum tersebut. Kurikulum yang diterapkan adalah Java Fundamental yang diintegrasikan dengan mata kuliah Pemrograman Berorientasi Objek (PBO). Seluruh materi telah disediakan oleh Oracle Academy berupa sistem elearning, materi digital, kuis, UTS, UAS dan tools untuk membantu perkuliahan. Seluruh materi, kuis, UTS, dan UAS adalah berbahasa Inggris sebagai pengantar, sehingga mahasiswa dituntut untuk menggunakan bahasa Inggris secara pasif. Berdasarkan uraian di atas, terkait permasalahan dalam pembelajaran $\mathrm{PBO}$, dan kelebihan yang ditawarkan oleh kurikulum yang ditawarkan oleh Oracle Academy, pada penelitian ini akan diuji pengaruh kemampuan berbahasa Inggris terhadap hasil belajar pemrograman berorientasi objek pada mahasiswa Jurusan Teknik Informatika. Penelitian yang diusulkan adalah korelasi. Pengambilan data dilakukan pada tahun ajaran 2018/2019. Jumlah mahasiswa yang mengikuti perkuliahan PBO adalah sebanyak 70 orang. Dari hasil analisis yang dilakukan dapat diambil kesimpulan bahwa kemampuan berbahasa Inggris tidak mempengaruhi hasil belajar PBO yang menggunakan kurikulum Oracle Academy.
\end{abstract}

Kata kunci: Oracle Academy, Java Fundamental, Pemrograman Berorientasi Obyek

\begin{abstract}
Oracle Academy is an initiative of Oracle to support computer science education in the world. Oracle Academy provides several ready-made curriculums for various educational institutions in the world. Department of Informatics, Faculty of Engineering and Vocational, Universitas Pendidikan Ganesha has also implemented one of these curricula. The curriculum applied was Java Fundamentals which was integrated with Object Oriented Programming (OOP) courses. All materials have been provided by Oracle Academy in the form of e-learning systems, digital materials, quizzes, midterm, final exam and tools to help lectures. All material, quizzes, midterm, and final exam were delivered in English, so students were required to use English passively. Based on the description above, related to problems in OOP learning, and the advantages offered by the curriculum offered by Oracle Academy, this study examine the correlation between English language abilities on objectoriented programming learning outcomes for students in the Department of Informatics. Data was collected in the 2018/2019 school year. The number of students who take OOP lectures was 70 people. From the results of the analysis conducted it can be concluded that English language proficiency does not affect OOP learning outcomes using the Oracle Academy's Java Fundamentals curriculum.
\end{abstract}

Keywords : Oracle Academy, Java Fundamental, Object Oriented Programming 


\section{PENDAHULUAN}

Pemrograman merupakan mata kuliah yang sangat penting di jurusan Teknik Informatika, Fakultas Teknik dan Kejuruan, Undiksha. Adapun bahasa pemrograman yang dipakai dalam praktik adalah Pascal, $\mathrm{C}_{++}$, dan Java. Semua bahasa pemrograman ini menggunakan kata/istilah dalam Bahasa Inggris. Meskipun demikian, bahasa pengantar yang digunakan pengampu mata kuliah pemrograman dalam pembelajaran adalah Bahasa Indonesia.

Pada tahun pertama perkuliahan, mahasiswa dikenalkan dengan mata kuliah-mata kuliah dasar di bidang informatika seperti matematika, algoritma, struktur data, basis data, dan pemrograman terstruktur. Sebuah program merupakan gabungan dari struktur data dan algoritma. Kode pada program terstruktur atau disebut juga program prosedural dieksekusi oleh interpreter/compiler secara berurutan mulai baris paling atas sampai paling bawah. Demikian juga pada fungsi/prosedur, urutanurutan kode dieksekusi baris demi baris.

Pembelajaran pemrograman ini dilaksanakan di laboratorium komputer, diawali dengan memberikan materi tentang konsep-konsep program, aturan-aturan penulisan, kemudian praktik membuat sebuah program. Praktik pemrograman dilakukan dengan memberikan contoh-contoh program jadi yang selanjutnya diketik dan dijalankan oleh mahasiswa. Setelah mahasiswa memahami program tersebut, dosen akan memberikan contoh kasus lain kepada mahasiswa untuk dibuatkan programnya. Program yang dibuat mahasiswa tersebut selanjutnya diperiksa oleh dosen dan diberikan masukan/umpan balik.

Pada tahun kedua, mahasiswa diberikan mata kuliah Pemrograman Berorientasi Obyek (PBO), dengan menggunakan bahasa pemrograman Java. Pada PBO satuan terkecil program adalah kelas. Konsep dasar dari PBO adalah abstraksi, enkapsulasi, polimorphisme, dan inheritance. Dan kelas yang bisa dieksekusi adalah kelas yang di dalamnya terdapat program utama (main). Selanjutnya, kelas main ini bisa memanggil kelas lainnya. Masalah yang ditemui adalah sulitnya mengubah kebiasaan mahasiswa yang sebelumnya menggunakan pemrograman procedural ke pemrograman berorientasi objek. Seperti data yang diperoleh dari hasil belajar PBO mahasiswa pada tahun 2016 mahasiswa belum menunjukkan hasil optimal pada penguasaan materi PBO yaitu pembentukan kelas, instanisasi kelas, maupun menggunakan kelas tersebut. Berdasarkan pengamatan, beberapa masalah yang dicurigai sebagai penyebabnya antara lain: kesulitan membuat kode-kode program, kurangnya kemampuan pemecahan masalah mahasiswa, dan kurangnya media pembelajaran PBO. $\mathrm{Hal}$ ini sejalan dengan penelitian Bashiru yang menyatakan bahwa masalah mahasiswa dalam belajar PBO adalah ketidakpahaman mahasiswa tentang apa yang terjadi di dalam komputer saat mengeksekusi program, ketidakpahaman tentang operasi memori, dan kesulitan dalam membangun program untuk menyelesaikan persoalan [1].

Oracle Academy merupakan sebuah inisiatif non-profit yang bergerak di bidang pendidikan dan pelatihan berbasis komputer yang ada di bawah perusahaan Oracle. Oracle Academy memiliki banyak kurikulum yang berkaitan dengan ilmu komputer yang siap digunakan oleh dosen untuk diajarkan ke mahasiswa. Seluruh materi dan media pembelajaran telah disediakan oleh Oracle Academy secara online. Salah satu kurikulum yang ditawarkan adalah Java Fundamental yang merupakan kurikulum PBO dengan memanfaatkan tools untuk membuat game sederhana sebagai sarana belajar PBO.

Tools yang digunakan pada kurikulum Java Fundamental adalah Alice dan Greenfoot. Alice dan Greenfoot adalah media berbasis visual yang dapat digunakan untuk belajar pemrograman, khususnya PBO. Kedua tools ini bisa dipakai untuk membuat game-game sederhana untuk menanamkan konsep-konsep PBO. Game komputer dapat menjadi alat pembelajaran yang berguna untuk pemrograman berorientasi obyek [2]. Bermain adalah salah satu cara utama dan efektif untuk mempelajari pengetahuan apapun yang mereka butuhkan. Game komputer dapat menjadi media pembelajaran yang menarik untuk proses pembelajaran. Penggunaan game dalam pembelajaran bisa meningkatkan motivasi mahasiswa untuk belajar, mendukung pemahaman konsep yang kompleks, dan melibatkan mereka dalam aktifitas pemrograman [3], [4]. Dengan menggunakan Alice dan Greenfoot, siswa bisa belajar cara membuat obyek, menggunakan obyek dengan memanggil metodemetode yang terkandung dalam obyek tersebut.

Seluruh kurikulum pada Oracle Academy menggunakan bahasa Inggris sebagai bahasa pengantar. Kuis, Ujian Tengah Semester (UTS) dan Ujian Akhir Semester (UAS) juga menggunakan bahasa Inggris. Maka dari itu mahasiswa dituntut untuk belajar PBO dengan menggunakan bahasa Inggris secara pasif. Berdasarkan uraian di atas, terkait permasalahan dalam pembelajaran PBO, dan kelebihan yang ditawarkan oleh kurikulum yang ditawarkan oleh Oracle Academy, pada penelitian ini menguji pengaruh kemampuan berbahasa Inggris terhadap hasil belajar PBO pada mahasiswa Jurusan Teknik Informatika. 


\section{STUDI LITERATUR}

\section{A. Oracle Academy}

Oracle Academy adalah sebuah inisiatif dari Oracle untuk mendukung pendidikan ilmu komputer di dunia [5]. Pada situsnya, Oracle Academy memiliki misi untuk memajukan pendidikan ilmu komputer secara global untuk mendorong pengetahuan, inovasi, pengembangan keterampilan, dan keragaman di bidang teknologi. Oracle Academy telah bekerja sama dengan berbagai instansi pendidikan di dunia dengan memberikan kurikulum yang dapat dimanfaatkan oleh pengajar. Oracle Academy juga menyediakan platform pembelajaran berbasis elektronik yang dapat diakses oleh mahasiswa dan dosen secara bebas. Oracle Academy memiliki beberapa kurikulum yang dapat digunakan, diantaranya adalah:

1. Java Fundamentals,

2. Java Foundations,

3. Java Programming,

4. Artificial Intelligence with Machine Learning in Java,

5. Database Foundations,

6. Database Design and Programming with SQL,

7. Programming with $\mathrm{PL} / \mathrm{SQL}$, dan

8. APEX - Application Development Foundations

Salah satu kurikulum yang paling populer dimanfaatkan di dunia adalah Java Fundamentals. Java Fundamentals adalah sebuah kursus yang mengenalkan konsep PBO, terminologi, sintaks, dan langkah-langkah yang dibutuhkan untuk membuat perangkat lunak berbasis Java. Hal yang unik pada kurikulum ini adalah, mahasiswa dikenalkan dengan konsep PBO melalui tools berbasis game 3D dan 2D [2]. Kedua tools tersebut adalah Alice dan Greenfoot. Alice dan Greenfoot merupakan Block-based programming environment dimana pengguna dapat memprogram dengan memanfaatkan sejumlah frame yang sudah disediakan dan menambahkan kode sesuai dengan kebutuhannya [6]. Seluruh materi disediakan melalui learning management system yang disebut Oracle Academy iLearning.

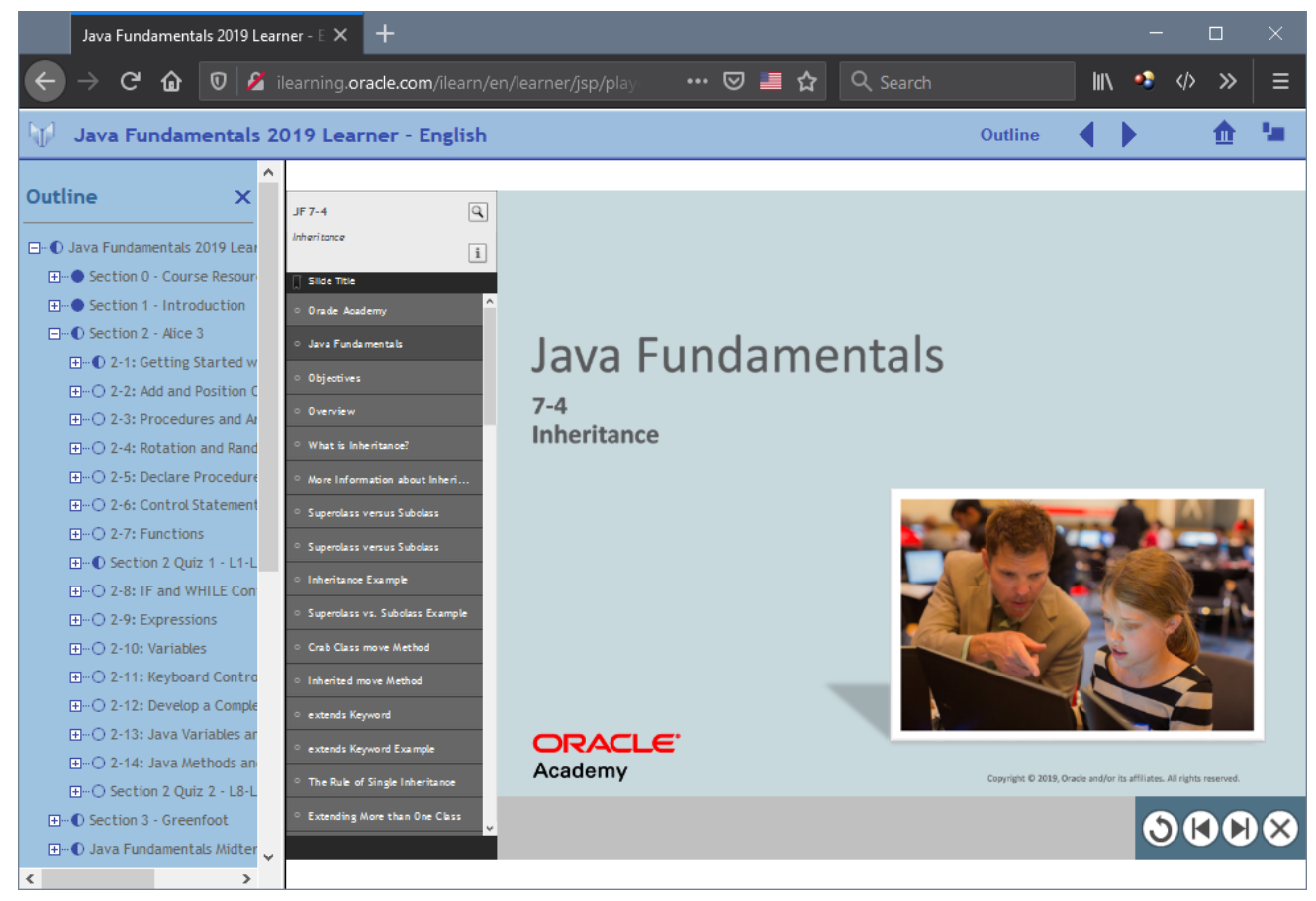

Gambar 1. Antarmuka Oracle Academy iLearning 


\section{B. Alice}

Alice adalah sebuah perangkat lunak yang ditujukan untuk mengajarkan pemrograman berbasis blok [7]. Alice memiliki antar muka 3D dimana pengguna dapat menyeret dan melepas (drag and drop) kontrol untuk melakukan banyak hal. Alice memiliki banyak obyek siap pakai, dimana obyek-obyek tersebut dapat diberi perintah sehingga dapat berinteraksi dengan pengguna. Hal ini juga dapat membuat pengguna untuk lebih tertarik dalam memulai untuk memprogram dan dapat digunakan sebagai alat untuk melakukan aktivitas kreatif [8]. Alice menggunakan konsep PBO dalam implementasinya, sehingga sangat cocok digunakan untuk mempelajari konsep dasar PBO.



Gambar 2. Antarmuka Alice 3

\section{Greenfoot}

Greenfoot adalah sebuah perangkat lunak interaktif yang digunakan untuk belajar konsep PBO melalui pembuatan game [9]. Greenfoot menggunakan bahasa pemrograman Java yang dibantu dengan berbagai class dan method yang siap untuk digunakan [10]. Berbeda dengan Alice, pengguna harus benar-benar melakukan menulis kode program dengan bahasa pemrograman Java. Namun, Greenfoot sudah menyediakan kelas-kelas dengan atribut dan metode siap pakai sehingga pengguna tidak perlu memikirkan hal-hal teknis dalam pembuatan game. Dengan memanfaatkan Greenfoot, pengguna dapat membuat game 2D sederhana dengan cepat dengan menggunakan konsep-konsep PBO.

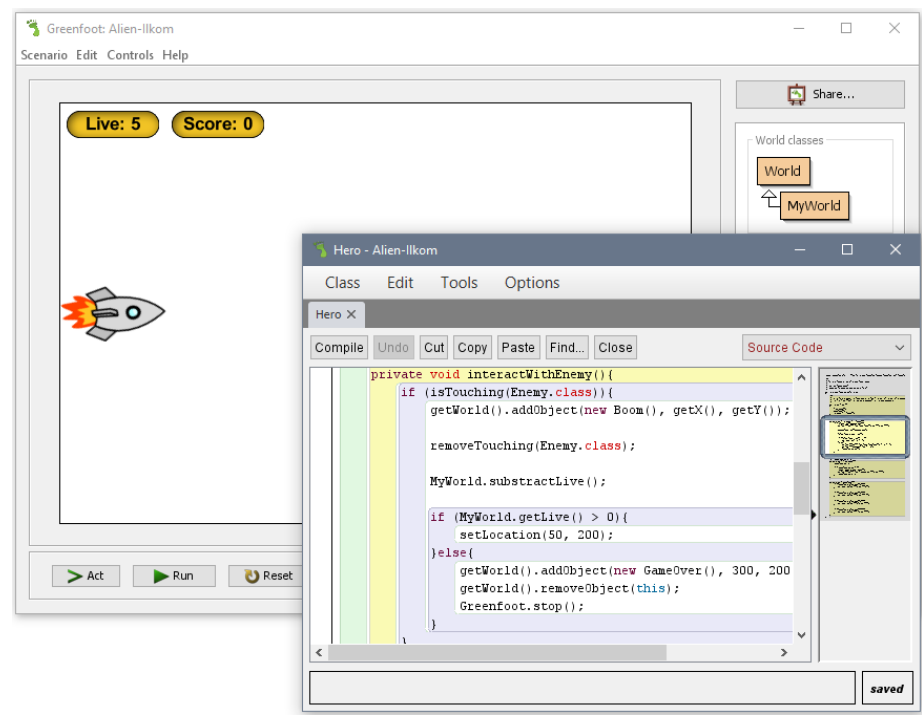

Gambar 3. Antarmuka Greenfoot 


\section{METODE}

Penelitian ini dilakukan bertujuan untuk mengetahui hubungan antara kemampuan berbahasa Inggris terhadap hasil belajar PBO mahasiswa dengan menggunakan kurikulum Oracle Academy, khususnya Java Fundamentals. Penelitian ini dilakukan di jurusan Teknik Informatika Fakultas Teknik dan Kejuruan Undiksha. Sampel Penelitian adalah mahasiswa Teknik Informatika yang mengambil dan mengikuti perkuliahan PBO semester genap tahun ajaran 2018/2019 dengan bobot 3 SKS. Jumlah mahasiswa yang diambil sebagai sampel adalah 70 orang mahasiswa berasal dari program studi Manajemen Informatika dan Pendidikan Teknik Informatika. Berikut ini adalah alur penelitian yang dilakukan:

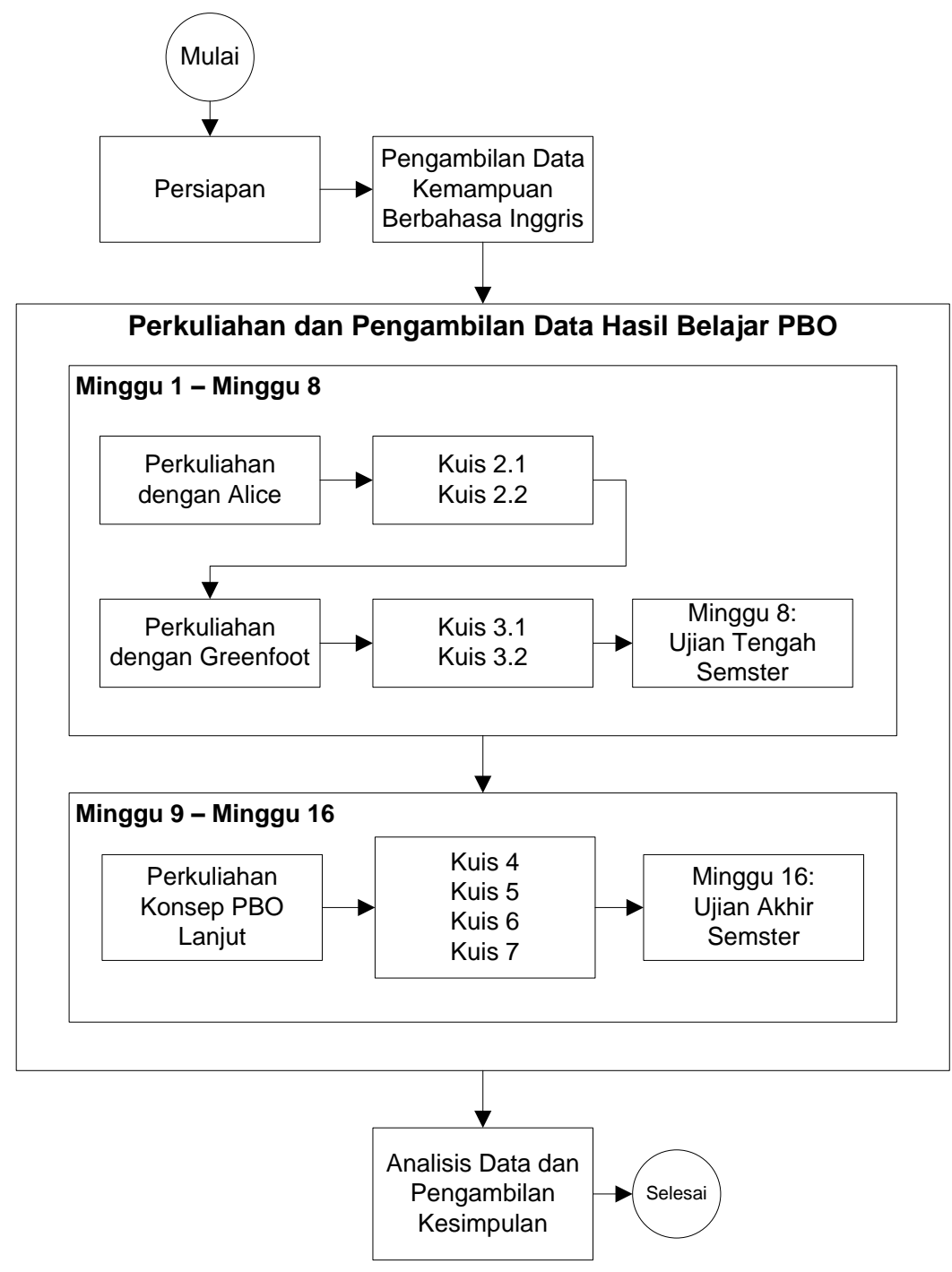

Gambar 4. Alur Penelitian

\section{A. Metode Pengumpulan Data}

Data kemampuan berbahasa Inggris diperoleh dengan menggunakan instrumen tes tulis dengan bentuk pilihan ganda sebanyak 30 soal. Soal yang digunakan diambil dari tes membaca berbahasa Inggris dari TOEFL. Data kemampuan berbahasa Inggris diambil pada pertemuan pertama perkuliahan PBO. Hasil belajar PBO diperoleh dari instrumen tes berbasis online yang disediakan Oracle Academy berbentuk pilihan ganda. Terdapat 7 kuis, UTS, dan UAS yang disediakan. Seluruh soal diambil dari bank soal yang dimiliki Oracle Academy yang ditampilkan secara acak. Pada Kuis, mahasiswa dapat mengulang kuis tanpa batasan waktu dan jumlah pengulangan. Sedangkan pada 
UTS dan UAS mahasiswa hanya diberikan kesempatan mengikuti sebanyak 1 kali. Data yang digunakan sebagai hasil belajar PBO adalah UTS dan UAS.

Dalam pembelajaran, penyampaian teori dan praktik dilakukan secara terintegrasi di ruang laboratorium Jurusan Teknik Informatika. Selama pembelajaran dosen membimbing mahasiswa menggunakan media Alice selama 4 pertemuan (3 jam/pertemuan), yang kemudian dilanjutkan dengan media Greenfoot selama 4 pertemuan. Setiap dua pertemuan, mahasiswa diberikan kuis secara online dan mahasiswa diberikan kebebasan waktu dalam menjawabnya. Setelah 8 pertemuan, mahasiswa diberikan ujian tengah semester, dengan materi ujian sesuai pertemuan-pertemuan sebelumnya. Selanjutnya, pada 8 pertemuan terakhir mahasiswa diberi materi berupa konsep dan implementasi PBO dengan bahasa pemrograman Java. Mahasiswa juga diminta untuk membuat proyek akhir berkelompok berupa membuat game sederhana dengan konsep-konsep PBO menggunakan Greenfoot.

\section{B. Teknik Analisis Data}

Penelitian ini menggunakan teknik analisis korelasi, karena variabel yang terlibat dalam penelitian ini ada dua, yaitu kemampuan berbahasa Inggris sebagai variabel bebas dan dilambangkan dengan $\mathrm{X}$ serta hasil belajar PBO mahasiswa sebagai variabel terikat dan dilambangkan dengan $\mathrm{Y}$. Berikut ini adalah langkah-langkah yang dilakukan untuk melakukan analisis korelasi:

\section{Uji Prasyarat}

Untuk melakukan uji korelasi, terdapat dua prasyarat utama yang harus dilakukan, yaitu uji normalitas dan uji linieritas. Uji normalitas dilakukan untuk memastikan bahwa variabel yang diuji berdistribusi normal. Uji normalitas menggunakan Kolmogorov-Smirnov. Uji linieritas adalah salah satu syarat yang harus dipenuhi dalam melakukan analisis regresi. Jika data yang diuji tidak linier, maka analisis regresi tidak dapat dilakukan. Uji linieritas dilakukan dengan $\mathrm{F}$ test dengan hipotesis sebagai berikut:

$$
\begin{aligned}
& \mathrm{H} 0=\text { Distribusi data tidak linier } \\
& \mathrm{H} 1=\text { Distribusi data linier }
\end{aligned}
$$

Selanjutnya nilai $\mathrm{F}$ dibandingkan dengan $\mathrm{F}$ tabel. Apabila $\mathrm{F}$ hitung kurang dari $\mathrm{F}$ tabel, maka $\mathrm{H} 0$ diterima, sebaliknya jika $\mathrm{F}$ hitung lebih besar dari $\mathrm{F}$ tabel, maka $\mathrm{HO}$ tidak diterima.

\section{Uji Korelasi}

Terdapat dua uji korelasi yang mungkin dapat digunakan tergantung dari kondisi data pada uji prasyarat. Jika kedua uji prasyarat, yaitu uji normalitas dan uji linieritas bernilai siginifikan, maka uji korelasi yang digunakan adalah Pearson Product Moment. Sedangkan, jika salah satu uji prasyarat tidak signifikan, maka uji yang digunakan adalah Spearman's rho. Berikut ini adalah hipotesis yang diusulkan:

H0: tidak ada korelasi antara kemampuan berbahasa Inggris dengan hasil belajar PBO $\mathrm{H} 1$ : ada korelasi antara kemampuan berbahasa Inggris dengan hasil belajar PBO

Selanjutnya, uji korelasi dilakukan dengan menggunakan SPSS dengan menggunakan teknik uji korelasi berdasarkan uji prasyarat yang dilakukan. Hasil uji korelasi digunakan untuk pengambilan kesimpulan.

\section{HASIL DAN PEMBAHASAN}

\section{A. Persiapan}

Persiapan yang dilakukan pada penelitian ini diantaranya adalah menyiapkan soal bahasa Inggris, dan menyediakan akun iLearning untuk mahasiswa. Soal bahasa Inggris diambil dari reading comprehension test dari TOEFL. Soal yang diambil sebanyak 30 soal dari 6 bacaan. Selanjutnya, akun iLearning disiapkan dosen dan disebarkan ke mahasiswa. Pada penelitian ini, terdapat 70 orang mahasiswa yang terlibat dari dua program studi, yaitu program studi Manajemen Informatika dan program studi Pendidikan Teknik Informatika. Setelah akun disebarkan ke mahasiswa, dosen memberikan pelatihan singkat tentang bagaimana menggunakan iLearning untuk perkuliahan PBO. 


\section{B. Pengambilan Data}

Terdapat 2 jenis data yang diambil untuk penelitian ini, yaitu data kemampuan berbahasa Inggris yang diambil dari TOEFL reading comprehension test; serta data hasil belajar PBO yang diambil dari kuis, midterm test, dan final test dari iLearning. Data kemampuan berbahasa Inggris diambil pada pertemuan pertama perkuliahan PBO. Setiap mahasiswa diminta untuk mengerjakan soal selama 60 menit. Terdapat 30 soal dengan rentang skor dari 0 hingga 30 . Data yang diperoleh dapat dilihat di Tabel 1.

Tabel 1. Data Skor TOEFL dan Nilai PBO

\begin{tabular}{ccc}
\hline No & $\begin{array}{c}\text { Skor } \\
\text { TOEFL }\end{array}$ & $\begin{array}{c}\text { Nilai } \\
\text { PBO }\end{array}$ \\
\hline 1 & 20 & 95,28 \\
2 & 21 & 97,17 \\
3 & 13 & 87,22 \\
4 & 15 & 86,23 \\
5 & 15 & 97,83 \\
6 & 16 & 87,11 \\
7 & 15 & 96,22 \\
8 & 12 & 93,33 \\
9 & 16 & 93,28 \\
10 & 14 & 89,50 \\
11 & 13 & 93,61 \\
12 & 17 & 95,28 \\
13 & 11 & 90,05 \\
14 & 11 & 90,89 \\
15 & 11 & 87,66 \\
16 & 12 & 82,00 \\
17 & 10 & 89,16 \\
18 & 14 & 91,39 \\
19 & 14 & 88,39 \\
20 & 10 & 89,94 \\
21 & 12 & 85,83 \\
22 & 16 & 95,39 \\
23 & 17 & 92,50 \\
24 & 8 & 88,00 \\
25 & 11 & 90,28 \\
\hline & & \\
& 14
\end{tabular}

\begin{tabular}{ccc}
\hline No & $\begin{array}{c}\text { Skor } \\
\text { TOEFL }\end{array}$ & $\begin{array}{c}\text { Nilai } \\
\text { PBO }\end{array}$ \\
\hline 26 & 12 & 92,78 \\
27 & 20 & 88,89 \\
28 & 14 & 83,72 \\
29 & 21 & 91,67 \\
30 & 12 & 79,11 \\
31 & 17 & 94,05 \\
32 & 16 & 95,67 \\
33 & 16 & 86,72 \\
34 & 12 & 89,00 \\
35 & 14 & 96,55 \\
36 & 19 & 87,61 \\
37 & 11 & 92,27 \\
38 & 10 & 92,05 \\
39 & 13 & 87,33 \\
40 & 17 & 83,95 \\
41 & 11 & 93,05 \\
42 & 16 & 90,22 \\
43 & 13 & 95,83 \\
44 & 14 & 86,72 \\
45 & 16 & 87,17 \\
46 & 16 & 96,72 \\
47 & 18 & 94,78 \\
48 & 15 & 93,11 \\
49 & 16 & 95,55 \\
50 & 16 & 93,05 \\
\hline & &
\end{tabular}

\begin{tabular}{ccc}
\hline No & $\begin{array}{c}\text { Skor } \\
\text { TOEFL }\end{array}$ & $\begin{array}{c}\text { Nilai } \\
\text { PBO }\end{array}$ \\
\hline 51 & 19 & 90,61 \\
52 & 15 & 80,83 \\
53 & 14 & 87,78 \\
54 & 15 & 88,94 \\
55 & 16 & 92,39 \\
56 & 19 & 96,78 \\
57 & 10 & 97,94 \\
58 & 15 & 94,56 \\
59 & 8 & 93,50 \\
60 & 13 & 96,55 \\
61 & 14 & 89,22 \\
62 & 11 & 87,28 \\
63 & 15 & 93,61 \\
64 & 9 & 92,61 \\
65 & 10 & 91,61 \\
66 & 9 & 92,89 \\
67 & 11 & 90,11 \\
68 & 13 & 92,66 \\
69 & 13 & 91,22 \\
70 & 11 & 86,44 \\
\hline & & \\
& &
\end{tabular}

Hasil belajar PBO diperoleh selama perkuliahan PBO berlangsung. iLearning menyediakan materi, tugas, kuis, midterm test, dan final test. Pada penelitian ini, hanya nilai kuis, midterm test, dan final test yang digunakan. Terdapat 7 kali kuis yang harus diselesaikan oleh mahasiswa. Soal kuis diberikan dengan pengantar bahasa Inggris. Kuis dapat dianggap tuntas pada saat mahasiswa memperoleh skor $>=70$ dari skor maksimal 100. Tidak ada batasan waktu jika mahasiswa gagal mencapai skor 70. Mahasiswa dapat mengulang hingga mencapai skor minimal tersebut. Untuk midterm test dan final test, mahasiswa dapat dikatakan tuntas jika memperoleh skor $>=60$ dari skor maksimal 100. Mahasiswa dapat mengulang sebanyak 2 kali jika tidak mencapai skor minimal tersebut. Selanjutnya seluruh skor dari kuis, midterm test, dan final test dirata-ratakan untuk memperoleh nilai akhir. Berikut ini adalah statistik deskriptif yang diperoleh:

Tabel 2. Statistik Deskriptif Skor TOEFL dan Nilai PBO

\begin{tabular}{lll}
\hline Statistik Deskriptif & TOEFL & PBO \\
\hline N & 70 & 70 \\
Mean & 13,98 & 90,98 \\
ST Dev & 3,01 & 4,15 \\
Variance & 9,61 & 17,25 \\
\hline
\end{tabular}




\section{Analisis Data}

Sebelum uji korelasi dapat dilakukan, terdapat dua uji prasyarat yang harus dilakukan yaitu uji normalitas dan uji linieritas. Uji normalitas dilakukan dengan menggunakan SPSS dimana hasilnya dapat dilihat pada Tabel 3. Dari data tersebut dapat dilihat nilai signifikansi nilai TOELF adalah 0,152 dimana nilai tersebut lebih dari 0,05 atau tidak signifikan. Hal ini menunjukkan bahwa sebaran data nilai TOELF mengikuti sebaran data normal. Sedangkan data nilai signifikansi untuk nilai PBO adalah 0,090 dimana nilai tersebut lebih dari 0,05 atau tidak signifikan. Hal ini menunjukkan bahwa sebaran data nilai PBO mengikuti sebaran data normal. Histrogram normalitas sebaran data dapat dilihat pada Gambar 5.

Tabel 3. Uji Normalitas

\begin{tabular}{lcccccc}
\hline \multicolumn{1}{l}{ Tests of Normality } \\
\cline { 2 - 7 } & Kolmogorov-Smirnov & \multicolumn{3}{c}{ Shapiro-Wilk } \\
\cline { 2 - 7 } & Statistic & df & Sig. & Statistic & df & Sig. \\
\hline TOFL Score & 0,089 & 70 & $\mathbf{0 , 2 0 0}$ & 0,974 & 70 & $\mathbf{0 , 1 5 2}$ \\
iLearning Score & 0,079 & 70 & $\mathbf{0 , 2 0 0}$ & 0,970 & 70 & $\mathbf{0 , 0 9 0}$ \\
\hline
\end{tabular}
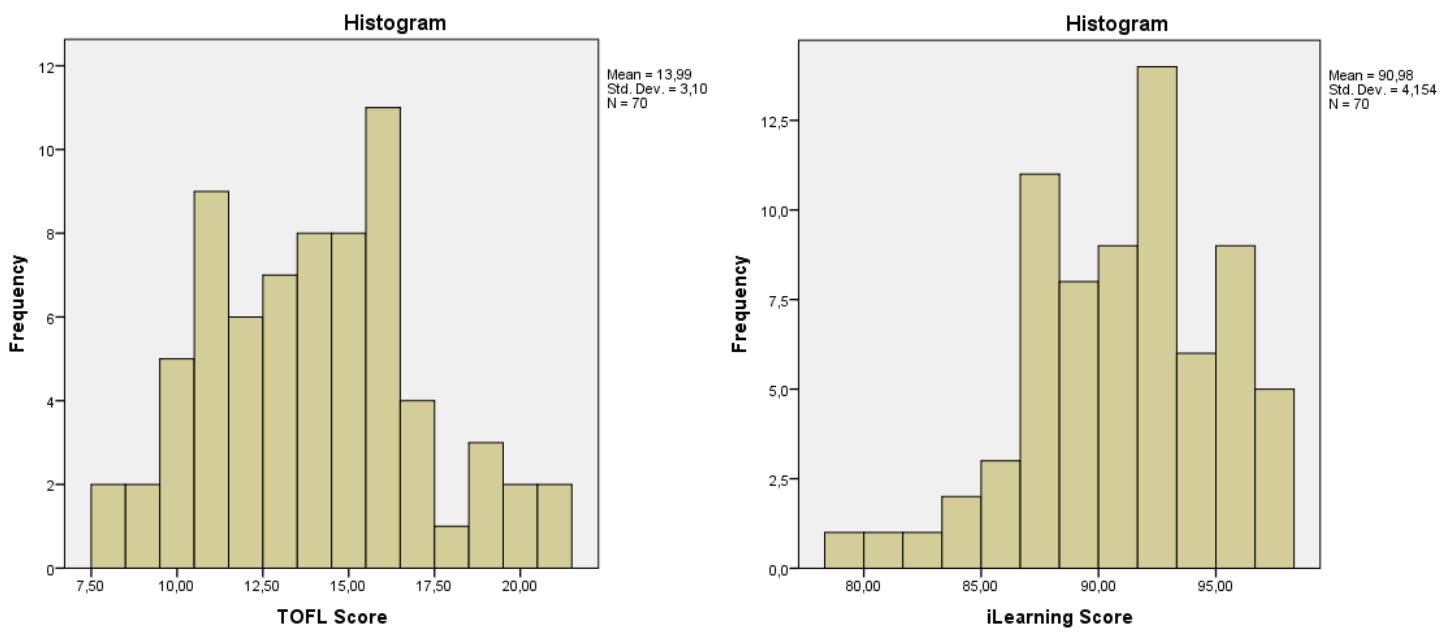

Gambar 5. Histogram Normaliatas Data

Uji prasyarat kedua (uji linieritas) dilakukan dengan menggunakan SPSS. Pada Tabel 4 dapat dilihat nilai signifikansi linieritas adalah 0,082 atau lebih dari 0,050 atau tidak signifikan. Hal ini menunjukkan bahwa data tidak linier.

Tabel 4. Uji Linieritas

\begin{tabular}{|c|c|c|c|c|c|c|c|}
\hline \multicolumn{8}{|l|}{ ANOVA Table } \\
\hline \multirow{6}{*}{$\begin{array}{l}\text { TOFL Score }{ }^{*} \\
\text { iLearning Score }\end{array}$} & \multirow{4}{*}{$\begin{array}{l}\text { Between } \\
\text { Groups }\end{array}$} & & $\begin{array}{l}\text { Sum of } \\
\text { Squares }\end{array}$ & $\mathrm{df}$ & $\begin{array}{l}\text { Mean } \\
\text { Square }\end{array}$ & $\mathrm{F}$ & Sig. \\
\hline & & (Combined) & 641,486 & 64 & 10,023 & 2,331 & 0,173 \\
\hline & & Linearity & 20,260 & 1 & 20,260 & 4,712 & 0,082 \\
\hline & & $\begin{array}{l}\text { Deviation from } \\
\text { Linearity }\end{array}$ & 621,226 & 63 & 9,861 & 2,293 & 0,178 \\
\hline & \multicolumn{2}{|c|}{ Within Groups } & 21,500 & 5 & 4,300 & & \\
\hline & \multicolumn{2}{|l|}{ Total } & 662,986 & 69 & & & \\
\hline
\end{tabular}


Berdasarkan kedua uji prasyarat di atas, dapat dilihat bahwa sebaran kedua data adalah normal, namun linieritas antar kedua data adalah tidak linier. Maka dari itu, uji korelasi yang dapat digunakan adalah uji Spearman's Rho. Tabel 5 adalah hasil uji korelasi Spearman's Rho dengan menggunakan SPSS. Hasil analisis menunjukkan bahwa kedua data tidak memiliki korelasi yang signifikan $(p>0,05)$. Dari hasil analisis di atas, dapat diambil kesimpulan bahwa tidak ada korelasi antara kemampuan berbahasa Inggris dengan hasil belajar PBO.

Tabel 5. Uji Korelasi

\begin{tabular}{lrrrr}
\hline Correlations & & & & \\
\hline \multirow{2}{*}{ Spearman's rho } & TOFL Score & Correlation Coefficient & 1,000 & 0,189 \\
\cline { 3 - 5 } & & Sig. (2-tailed) & - & $\mathbf{0 , 1 1 8}$ \\
& & $\mathrm{N}$ & 70 & 70 \\
\cline { 3 - 5 } & iLearning Score & Correlation Coefficient & 0,189 & 1,000 \\
& Sig. (2-tailed) & $\mathbf{0 , 1 1 8}$ & - \\
& $\mathrm{N}$ & 70 & 70 \\
\hline
\end{tabular}

\section{SIMPULAN DAN SARAN}

Penelitian telah dilakukan dengan melibatkan 70 mahasiswa pada mata kuliah PBO. Mata kuliah PBO menggunakan Oracle Academy iLearning dengan pengantar berbahasa Inggris. Penelitian ini bertujuan untuk mengetahui apakah kemampuan berbahasa Inggris mempengaruhi hasil belajar PBO dengan pengantar berbahasa Inggris. Data menunjukkan bahwa tidak ada korelasi yang signifikan antara kemampuan berbahasa Inggris (ditunjukkan dari nilai TOEFL reading comprehension test) dengan hasil belajar PBO (ditunjukkan dari rerata nilai kuis, midterm test, dan final test pada Oracle Academy iLearning). Hal ini menunjukkan bahwa kemampuan berbahasa Inggris tidak mempengaruhi hasil belajar PBO dengan memanfaatkan kurikulum Oracle Academy. Beberapa penelitian menunjukkan bahwa keberhasilan implementasi kurikulum Oracle Academy untuk mata kuliah PBO lebih dipengaruhi oleh level kepuasan mahasiswa dalam menggunakan tools berbasis visual seperti Greefoot dan Alice [11][12]. Sehingga untuk mata kuliah sejenis, kemungkinan akan memiliki kecenderungan yang sama. Kesimpulan di atas dapat dijadikan sebagai dasar dalam menerapkan kurikulum Oracle Academy pada lingkungan yang lebih luas di jurusan Teknik Informatika. Dosen tidak perlu khawatir dengan kemampuan berbahasa Inggris mahasiswa dalam menerapkan kurikulum dengan pengantar berbahasa Inggris. Hal ini juga dapat dijadikan dasar pada mata kuliah lainnya yang ingin menggunakan atau mengadopsi kurikulum yang digunakan di industri dimana pada umumnya menggunakan bahasa Inggris sebagai pengantar.

\section{DAFTAR PUSTAKA}

[1] L. Bashiru and A. A. Joseph, "Learning Difficulties of Object Oriented Programming (OOP) in University of llorin - Nigeria : Students 'Perspectives," in Proceedings of Eighth ThellERScience Plus International Conference, 2015, no. January, pp. 64-69.

[2] W. Y. Seng and M. H. M. Yatim, "Computer Game as Learning and Teaching Tool for Object Oriented Programming in Higher Education Institution," Procedia - Soc. Behav. Sci., vol. 123, no. March, pp. 215-224, 2014.

[3] U. Theodoraki and S. Xinogalos, "El estudio de actitudes de los estudiantes sobre el uso de ejemplos de código fuente del juego para el aprendizaje de la programación," Informatics Educ., vol. 13, no. 2, pp. 265-277, 2014.

[4] S. Sharma, J. Stigall, and S. Rajeev, "Game-theme based instructional module for teaching object oriented programming," in Proceedings - 2015 International Conference on Computational Science and Computational Intelligence, CSCI 2015, 2016, pp. 252-257.

[5] F. Urem, E. Ban, and D. Jurekovic, "Enhancing digital competences of Croatian teachers of informatics - Oracle academy use case," in 2018 41st International Convention on Information 
and Communication Technology, Electronics and Microelectronics, MIPRO 2018 -

Proceedings, 2018, no. May, pp. 605-609.

[6] T. W. Price, N. C. C. Brown, D. Lipovac, T. Barnes, and M. Kölling, "Evaluation of a framebased programming editor," in ICER 2016 - Proceedings of the 2016 ACM Conference on International Computing Education Research, 2016, pp. 33-42.

[7] J. Dwarika and M. R. R. De Villiers, "Use of the Alice visual environment in teaching and learning object-oriented programming," in ACM International Conference Proceeding Series, 2015, pp. 1-10.

[8] K. Hayat, N. A. Al-Shukaili, and K. Sultan, "Alice in Oman: A study on object-first approaches in computer science education," Educ. Inf. Technol., vol. 22, no. 4, pp. 1553-1569, 2017.

[9] M. Kölling, "Lessons from the Design of Three Educational Programming Environments," Int. J. People-Oriented Program., vol. 4, no. 1, pp. 5-32, 2016.

[10] M. Kölling and F. McKay, "Heuristic evaluation for novice programming systems," ACM Trans. Comput. Educ., vol. 16, no. 3, 2016.

[11] N. Z. Dina, E. Wuryanto, and R. S. Marjianto, "Evaluation on the effectiveness of visual learning environment on programming course from students' perspectives," IIUM Eng. J., vol. 20, no. 1, pp. 100-107, 2019.

[12] I. Supriana, R. D. Agustin, M. A. Bakar, and N. A. M. Zin, "Serious games for effective learning," in Proceedings of the 2017 6th International Conference on Electrical Engineering and Informatics: Sustainable Society Through Digital Innovation, ICEEI 2017, 2018, pp. 1-6. 